\title{
Flumazenil in Treatment Benzodiazepine Withdrawal Syndrome: Case report
}

\author{
Aleksandar J. Ramah ${ }^{1}$, Mirjana M. Todorović ${ }^{1}$, Katarina B. Crnić ${ }^{2}$ \\ ${ }^{1}$ Specialised psychiatric private practice "Ramah", Belgrade, Serbia \\ ${ }^{2}$ Special hospital for substance abuse, Belgrade, Serbia
}

\section{SUMMARY}

Background: Today in the world and in Serbia is growing number of people who are addicted to benzodiazepine. A particular problem is the process of detoxification and treatment of benzodiazepine withdrawal syndrome due to a recurrence of symptoms of anxiety disorder, availability of benzodiazepines, falling motivation. Standard procedures have often proved unsuccessful and the last decade, and the search for new protocols, including the flumazenil, benzodiazepine receptor antagonist, is actualized.

Case report: The patient aged 48 years was admitted to the specialist psychiatric clinic, for treatment of benzodiazepine addiction. Anxiety disorder was diagnosed since adolescence perennial addiction on benzodiazepines and the initial withdrawal syndrome. Former motivated topical treatments for detoxification were unsuccessful. The presence of dual diagnosis, persistence of both disorders in perennial cycle, treatment resistance and actual motivation contributed to the decision to opt rapid detoxification from benzodiazepines by flumazenil application protocol, for hospital treatment by adjuvant therapy with lamotrigine. After discharge from hospital in stable condition it was with no signs of withdrawal syndrome and a rebound of anxiety symptoms. Lamotrigine medication continued including CBT, held during the one-year abstinence monitoring, with sufficient social functionality.

Discussion: The efficacy and safety of flumazenil in the treatment of benzodiazepine withdrawal syndrome was investigated in numerous clinical trials, and the mechanism of action is complex, from the benzodiazepine antagonist to inverse agonist in certain circumstances, as well as "up-regulation" receptors, which together leads to a reduction in symptoms of abstinence syndrome and anxiety in the longer term after treatment, thereby acting favorably to the adherence and remission.

Conclusions: Flumazenil protocol is an efficient method in the treatment of the benzodiazepine withdrawal syndrome. Given the existence of certain concerns and relatively little experience in this procedure, it is necessary to define further all aspects of the procedure.

Keywords: benzodiazepines, dependency, detoxification, flumazenil

\section{INTRODUCTION}

Since the introduction of chlordiazepoxide in medical and psychiatric practice in 1960 , the indications for benzodiazepines expended. Except in psychiatry, benzodiazepines are used in neurology, internal medicine and cardiology, anesthesiology, physical therapy and 
other domains. The prevalence of long-term use, mostly large doses of benzodiazepines in the general population is $2-7 \%$ and among people who use benzodiazepines $25-76 \%$ [1]. With the increase in applications grew problems related to benzodiazepines: intoxication (accidental and intentional) and addiction (iatrogenic and non-iatrogenic). All benzodiazepines have the potential to create addiction on the term that those with short duration effect cause addiction more frequently and faster (primarily midazolam, lorazepam). In 15-44\% of people on long-term (4-6 weeks) taking benzodiazepines, will be present a moderate to severe withdrawal syndrome after abrupt discontinuation of benzodiazepines [2]. It is a serious medical condition with polymorphic symptoms that require drug treatment.

Initial abstinence syndrome is $2-5$ days after discontinuation and the symptoms can be present for several weeks. Most of the symptoms are not specific: there are insomnia, restlessness, irritability, fear, apathy and lethargy, nausea, tremors, muscle tension, sweating, rapid heartbeat. Increased sensitivity to noise, light and other stimuli are specific. There may be more difficult and more serious disorders: epileptic seizures grand mal type, hallucinations, delirium, psychomotor agitation, delusions and suicidal thoughts [3.4].

\section{CASE REPORT}

The patient, aged 48 years, was admitted for psychiatric evaluation and treatment of benzodiazepine addiction in specialist psychiatric clinic.

In history, the main problems were hand tremor, anxiety, agitation, anxiety, moodiness, pessimistic thoughts as well as the general decline in efficiency and functionality by severe absenteeism in professional activities.

Present illness lasts from early adolescence; it was diagnosed as anxiety disorder and was not treated at that time. After moving out of Serbia abroad in 1992, together with her family, fear, insecurity and her physical symptoms worsened and then she started on her own initiative to take anxiolytics, occasionally at first, later every day, increasing the dose and often combining with alcohol, primarily in order to function at work (hand tremor disabled her professional activities). She was treated for the first time in 2007 psychiatrically in her country due to immoderate drinking of alcoholic beverages and taking large doses of benzodiazepines (clonazepam of up to $14 \mathrm{mg}$. per day). Since then, she does not drink alcohol but a few months after she started taking clonazepam in daily doses of 6 to $12 \mathrm{mg}$. and to this treatment she has taken it practically continuously (abstinence extremely rare and short-lived, 2-3 days). For the second time, she was psychiatrically treated in Serbia, 2010, due to persistence of anxiety disorders while taking clonazepam she presented as sporadic to her therapist. Upon her return to native country, she continued taking clonazepam in larger doses. Therapeutic doses prescribed by her physician, were modified with clonazepam, which she purchased on the 'black market'. She recently managed to reduce the daily dose of clonazepam at 5-7 $\mathrm{mg}$, with regular therapy venlafaxine $150 \mathrm{mg}$ daily (prescribed by the doctor). In the personal history of the regular development, she is successful in education, from childhood prone to fears, uncertain, anxious in social situations. She graduated from medical school and she is working in the country of residence as a nurse. Her marriage is satisfactory and she has an adult daughter.

The family history has no significant psychiatric diseases.

On admission, mental status is dominated by symptoms and signs of anxiety, dysphoria, depressed ideation, with a mild psychomotor retardation and initial withdrawal symptoms. Insight was adequate; she was motivated for detoxification of anxiolytics.

The patient was diagnosed as anxiodepressive disorder F 41.2 and addiction on benzodiazepines F13.2.

Given the dual diagnosis and duration of both disorders for significantly long period of time in the past, failure of previous treatment because of apparent withdrawal symptoms and basic Anxio depressive disorder, the intention of the patient was accepted to carry out detoxification of benzodiazepines. Protocol flumazenil $[5,6]$ was suggested to her, with the adjuvant medication in the hospital conditions.

Protocol started after routine internistic assesment. and with the consent of the patient prior informed (information on all aspects of this method). Venous line was established and the initial dose of $1 \mathrm{mg}$ of flumazenil was applied in $500 \mathrm{ml}$ of saline through several hours of infusion. According to the 
protocol, over the next four days flumazenil was administered in a daily dose of $2 \mathrm{mg}$, with permanent monitoring of psychological and physical condition. In order to prevent the risk of seizures and an additional antianxiety and antidepressant activity, the patient was administered upon receiving lamotrigine fast-track scheme to $125 \mathrm{mg}$ per day for three days, and it was continued with the same level onwards. During the entire period, vital signs were stable and psychological status was not registered as psychopathological problems.

The patient did not verbalize subjective symptoms therefore the initial high motivation was maintained.

On the fifth day, patient was discharged in stable psycho-physical condition. After seven days, once was administered $2 \mathrm{mg}$ of flumazenil in an hours-long infusion with the idea to further stabilize the benzodiazepine receptors.

In terms of hospitalization, psychotherapy process was modified and reduced to a support level, ventilation, maintenance of motivation and preparation for appropriate prolonged psychotherapeutic process. Implemented protocol was extremely successful and safe to which certainly contributed highly motivated patients and psychiatric preparation before hospitalization and support during hospitalization, both from professional and social network.

The procedure was carried out in 2014 and immediately upon release is included in the REBT (rational-emotional-behavioral therapy), which is still on going. Annual monitoring suggests maintaining abstinence and that in family, social and professional sense it is not only reintegrated but also completely functional.

\section{DISCUSSION}

The treatment of benzodiazepine withdrawal syndrome is a complex and serious medical problem. Faced with this, clinicians have developed several protocols for treatment. The initial clinical approach to a sudden discontinuation is replaced by a reductive scheme of different duration, with or without the support of other psychopharmaceuticals. Benzodiazepine dose is reduced or benzodiazepine is introduced with longer effect of equivalent dose or other drugs are introduced (primarily psychostabilizers - lamotrigine, carbamazepine, valproate) administered upon discontinuation of benzodiazepine. Long-term substitution treatment in people at high doses of benzodiazepines and the structural changes of personality [7] is less commonly implemented. The main drawback of this approach is the very length of detoxification, which can range from 2-3 weeks to several months, which greatly affects the efficiency and comfort of the procedure. Due to the possible presence of abstinence problems and desire for effects, people often forgo treatment and return to taking benzodiazepines.

From pioneering protocols introduced by Gilberto Gerra (working at Centro Studi Farmacotoxico Substance Abuse Service, Parma, Itally) $[8,9]$ in 2002 in which he confirmed the effectiveness of flumazenil in the treatment of benzodiazepine withdrawal syndrome, the effectiveness of flumazenil [3, 9,10 , and 11] was investigated in several studies. Protocol established at 9 th Stupleford's International Addiction Conference in 2008 by G.O'Neil, G.Hulse and CT.Chan includes 2-4 $\mathrm{mg}$ of flumazenil intravenous application, during 4-7 days, with the possibility of subsequent booster doses, depending on the condition of the patient.

The mechanism of flumazenil effect is manifold. Introduced in the clinical application of the 1990's in the $20^{\text {th }}$ century, as a benzodiazepine antagonist, flumazenil is primarily used in the case of benzodiazepine intoxication and, if necessary in the postoperative recovery if it is used benzodiazepine premedication. Further clinical practice and research confirms that flumazenil mainly acts as a "silent" receptor antagonist on the benzodiazepine receptor of the GABA-A complex, and is active only in the presence of benzodiazepines, replacing them, which explains its effect on reducing withdrawal symptoms and anxiety reduction. However, in certain circumstances, the modification in the receptor complex GABA-A, which is the case with the long-term anxiety disorders (in panic disorder primarily) or in cooperation with chronic use of benzodiazepines, it can act as a benzodiazepine inverse agonist, i.e. increased anxiety [12]. Clinical effect of flumazenil therefore varies depending on the circumstances and basic disorder in a patient. Also, there are indications that flumazenil has the ability to reduce prolonged symptoms of benzodiazepine withdrawal syndrome sometimes a few months (or longer) after discontinuation of polymorphic persistence 
of symptoms $[13,14,15]$. The assumption is that flumazenil can 'reset 'benzodiazepine receptor functions. Particularly, the chronic (high) doses of benzodiazepines lead to allosteric alterations of benzodiazepines receptors and reduce affinity both for the benzodiazepine receptors and for GABA receptors in GABA-A macromolecular receptors complex. Flumazenil works by replacing (suppressing) the benzodiazepine from receptors and possibly inducing 'up regulation' of benzodiazepine receptors leading to their normalization [6.9]. Despite the good results so far, many aspects of this procedure must be tested and [15], it is necessary to answer the numerous questions: - In respect of which doses and length of taking benzodiazepines should be recommend and implemented flumazenil protocol?

- Should flumazenil protocol be used only if the reduction of benzodiazepines does not work?

- Can the protocol be adopted also for those with a history of seizures?

- How to optimize the dose of flumazenil as well as the length and route of administration? For now, it is thought that better long-term effects are achieved by administration (during the day), while the overall length of treatment remains open question.

- What adjuvant medications can optimize treatment?

- Is there any justification for thinking about longer-lasting treatment of flumazenil as other partial agonists - buprenorphine successfully implemented in the treatment of opiate addiction and varenicline addiction on nicotine?

In conclusion, addiction on benzodiazepines today represents a significant medical - psychiatric problem and most prominent form of iatrogenic addiction, while the treatment of benzodiazepine apstinential syndrome is complicated and has uncertain outcomes. As flumazenil protocol gave promising results, further studies and approvement of clinical studies with a larger number of subjects are needed which will confirm the applicability, efficacy and safety of this method.

\section{Interest conflict statement:}

The authors confirm there is no potential interest conflict.

\section{REFERENCES}

1. Fang SY, Chen CY, Chang IS, WU EC, Chang CM,
Lin KM. Predictors of the incidence and discontinuation of long term use of benzodiazepines: a population based study. Drug Alcochol Depend. 2009; 104: 140-146

2. De las Cuevas C, Sanz EJ, de la Fuente JA, Padilla J, Berenguer JC. The Severity of Dependency Scale(SDS) as screening test for benzodiazepine dependence: SDS validation study. Addiction. 2009; 95: $245-250$

3. Hood S, O'Neil G, Hulse G. The role of flumazenil in the treatment of benzodiazepine dependence : physiological and psychological profiles. J Psychopharmacol. 2009; 23: 401-409

4. Ramah A. Psihoaktivne supstance- dejstva, posledice, lečenje. Interprint, Beograd. 2001; 20-23

5. Gerra G, Zaimovich A, Giusti F, Moi G, Brewer C. Intravenius flumazenil versus oxazepam tapering in the treatment of benzodiazepine withdrawal: a randomized, placebo-controlled study. Addict Biol. 2002; 7: 385-395

6. O'Neil G, Hulse G, Chan CT. Outpatient ambulatory rapid benzodiazepine detoxification. 9 th Stupleford International Addiction conference, Athens 2008, Book of abstracts P743

7. Ragia G, Manolopulos V.G. Pharmacogenomics of alcohol addiction: personalizing pharmacologic treatment of alcohol dependence

8. Liebrenz M, Boesch L, Stohler R, Caflisch C. Agonist substitution- a treatment for high-dose benzodiazepine-dependent patients? Addiction.2010; 105: 1870- 1874

9. Quaglio GL, Pattaro C, Gerra G, Mahewson S, Verbanck P, Des Jarlais DC, Lugoboni F. High dose benzodiazepine dependence: description of 29 patients treated with flumazenil infusion and stabilized with clonazepam. Psychiatry Res. 2012; 198: 457- 462

10. Lader M,. Benzodiazepines revisited- will we ever learn? Addiction. 2011; 106: 2086- 2109

11. Lugoboni F, Leone R. What is stopping us from using flumazenil? Addiction. 2012; 107: 1359

12. Stahl, SM. Stahl's essential psychopharmacology: neuroscientific basis and practical application, Forth edition, 2012. Cambrige University press

13. Lader Mh, Morton SV. A pilot study of the effects of flumazenil on symptoms persisting after benzodiazepine withdrawal. J Psychopharmacol. 1992; Vol 6, 3: 357-363

14. Saxon L, Hjemdahl P, Hiltunen AJ, Borg S. Effects of flumazenil in the treatment of benzodiazepine withdrawal- a double-blind pilot study. Psychopharmacology (Berl). 1997; 131(2): 153-60

15. Hood SD, Norman A, Hince DA, Melichar JK, Hulse GK. Benzodiazepine dependence and its treatment with low dose flumazenil. Br J Clin Pharmacol. 2014; 77(2): 285-94 


\title{
Flumazenil u tretmanu benzodiazepinskog apstinencijalnog sindroma: prikaz slučaja
}

\author{
Aleksandar J. Ramah ${ }^{1}$, Mirjana M. Todorović ${ }^{1}$, Katarina B. Crnić ${ }^{2}$ \\ ${ }^{1}$ Specijalistička psihijatrijska ordinacija „Ramah“, Beograd, Srbija \\ ${ }^{2}$ Specijalna bolnica za bolesti zavisnosti, Beograd, Srbija
}

\section{KRATAK SADRŽAJ}

Uvod: Danas u svetu kao i u Srbiji raste broj osoba koje su zavisne od benzodiazepina. Poseban problem predstavlja proces detoksikacije odnosno tretman benzodiazepinskog apstinencijalnog sindroma zbog povratka simptoma anksioznog poremećaja, dostupnost benzodiazepina, pada motivacije. Standardne procedure su se često pokazale neuspešnim pa se poslednjih desetak godina u svetu traga za novim protokolima medju kojima je i flumazenil, antagonist benzodiazepinskih receptora.

Prikaz slučaja: Pacijentkinja stara 48 godina je primljena u specijalističkoj psihijatrijskoj ordinaciji, radi tretmana zavisnosti od benzodiazepina. Dijagnostikovan je anksiozni poremećaj od adolescencije višegodišnja zavisnosti od benzodiazepina i početni apstinencijalni sindrom. Dosadašnji tretmani neuspešni, aktuelno motivisana za detoksikaciju. Prisutnost dualne dijagnoze, perzistencija oba poremećaja u višegodišnjem periodu, teraporezistencija i aktuelna motivisanost su opredelili odluku o brzoj detoksikaciji od benzodiazepina, primenom protokola flumazenilom, u hospitalnim uslovima, uz adjuvantu terapiju lamotriginom. Po otpustu u stabilnom stanju, bez znakova apstinencijalnog sindroma i rebound anksioznih simptoma. Nastavljena je medikacija lamotriginom, uključena CBT, tokom jednogodišnjeg praćenja održava apstinenciju, uz zadovoljavajuću socijalnu funkcionalnost.

Diskusuja: Efikasnost i bezbednost flumazenila u tretmanu benzodiazepinskog apstinencijalnog sindroma je ispitivana u brojnim kliničkim studijama, dok je mehanizam dejstva složen, od benzodiazepinskog antagonista, do inverznog agonista u određenim okolnostima, kao i „up-regulation“ receptora, što zajedno dovodi do smanjenja simptoma apstinencijalnog sindroma i anksioznosti i u dužem periodu po tretmanu, delujući time povoljno na adherencu i remisiju.

Zaključak: Flumazenil protokol predstavlja efikasnu metodu u tretmanu benzodiazepinskog apstinencijalnog sindroma. S obzirom na postojanje odredjenih nedoumica i relativno mala iskustva u ovoj proceduri, neophodno je dalje definisanje svih aspekata procedure.

Ključne reči: benzodiazepini, zavisnost, detoksikacija, flumazenil 